\title{
定量的運動負荷試験および呼吸筋力測定 による肺切除術症例の術前評価
}

\author{
岡山大学医学部第二外科学教室（指遒：寺本 滋教授) \\ 大㷊浩介
}

(平成 3 年 3 月 6 日受稿)

\begin{abstract}
Key words：定量的運動負荷試験，呼吸筋力，肺切除術，術後合併症， 酸素摄取指数
\end{abstract}

\section{緒}

肺切除術において耐術能を判定するための術 前検查としては従来，肺活量，1秒量などの肺 気量の測定が中心であったが，最近では心肺機 能予備力あるいは酸素拱取予備能力という観点 から運動負荷試験による術前評価が注目されて いる.しかし，これらの運動負荷試験では通常， symptom limited までの最大運動負荷を被験者 に加えて得られたパラメータが主に検討されて おり，特に最大酸素摄取量 $\dot{\mathrm{V}}_{2} \max$ と術後合 併症，術死との関連性について多数の報告がな されている(12)334).一方，肺手術対象者は年々高 齢化の傾向を呈しており，被験者の自発的努力 に大きく依存する最大運動負荷試験は，特に高 齢者や，無気力な患者では実施に困難を感じる 場合があり，そのことが運動負荷試験のルチー ン化を防げる要因となっている可能性が高い. 最近では submaximal な運動負荷量で耐術能を 推定しようとする試みも報告されている.Olsen ら ‘門塞性肺障害を有する52例の肺腫瘍術前患 者に40wattsの定量的運動負荷を施行し，その ときの $\dot{\mathrm{VO}}_{2}$ が耐術できた群に比べて耐術できな かった群で有意に低值であったと述べて，定量 的運動負荷試験の有用性を示唆している.また, 換気の generator としての呼吸筋力の評価も最 近注目されてきており，呼吸筋力と運動能力や 呼吸不全との関連が研究されている. Dillard ら は一般肺機能検查と呼吸筋力の測定值から $\dot{\mathrm{VO}}_{2}$ $\max$ の推定が可能であるとし, 呼吸筋力が $\dot{\mathrm{V}}_{2}$ $\max$ の決定因子の一つとなりうる可能性を指摘 している、そこで，著者は総合的な術前患者評 価の手段として従来の一般肺機能検查に加えて, トレッドミルによる submaximal な中等度の定 量的運動負荷試験と呼吸筋力の測定を施行し， その有用性および術後心肺合併症発生との関連 性について検討した。

\section{対象と方法}

\section{1. 対 象}

平成元年 3 月から, 平成 2 年 2 月までの 1 年 間に岡山大学第二外科に入院した肺切除対象患 者で，明らかな心娭患を有しない73例（男性51 例，女性22例）を対象とした，年跲分布は37歳 から82歳までで平均 $63.0 \pm 10.9$ 歳であった。疾 患別では原発性肺癌60例, 転移性肺腫瘍 3 例, 良性肺疾患10例であった。良性疾患の内訳は結 核腫，過誤腫，気管支腺腫が各々 2 例ずつ，そ の他サルコイドーシス，偽リンハ腫，気管支拡 張症，器質化肺炎が各々1例ずつであった。対 象とした73例中 4 例は，入院後の精查中に遠隔 転移の発見や組織型が小細胞癌と診断された理 由で手術非適応とされ，69例に肺切除術が施行 巳れた，手術方法は肺全摘術 7 例（右肺 1 例, 左肺 6 例)，二肺葉切除術 4 例，一肺葉切除術 48 例，部分切除術10例であった。術前に一般肺機 能検查に加之て定量的運動負荷試験および呼吸 筋力の測定を行い，手術例のうち45例では術後 3 週間から 4 週間の時点で術前と同様の肺機能 検查拐よび運動負荷試験を施行した。 
2. 万法

1）一般肺機能検查

脯切除予定患者73例に対して，千ェスト社製 䶺機能測定システムCHESTAC-65Vを使用し， $\mathrm{VC}$ (肺活量)， $\mathrm{FEV}_{1.0} / \mathrm{m}^{2}$ (体表面䄽あたりの1 秒量)，MVV (最大換気量)，DLco/VA (一回 呼吸法一酸化炭素拡散能）を测定した。また自 覚的呼吸困難の程度を問診により, Hugh-Jones 分類にしたがって評価した.

\section{2）運動負荷試験}

蹗動負荷試験は電動式トレッドミルを用いた， まずトレッドミルによる歩行に慣れるため，数 分の歩行予備練習の後, 図1に示すよjに 2 分 間の立位安静の後， $2 \mathrm{METs}$ (傾斜角 $0 \%$ ，速度 $2 \mathrm{mph}$ )を 4 分間, 続いて 4 METs(傾斜角 $7 \%$,

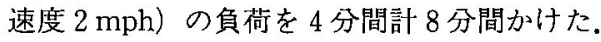
ただし，年跉70歳以上あるいは身長 $150 \mathrm{~cm}$ 以下の 患者には速度を $1.7 \mathrm{mph}$ に減じた。試験中は患 者には心電図モニターおよびフェースマスクを 装着して呼気ガスを採取し，呼吸代謝測定装置 (日本電気三栄製エアロビクスプロセッサ391) で1分毎に， $\mathrm{VO}_{2}$ (酸素搨取量)， $\dot{\mathrm{V}} \mathrm{CO}_{2}$ (炭酸 ガス排泄量)， $\mathrm{VE}$ (換気量), 呼吸数, 心拍数を 測定, $\dot{\mathrm{V}} \mathrm{O}_{2} / \dot{\mathrm{VE}}$ (酸素利用率) および $\mathrm{O}_{2}$ pulse （酸素脈）を求妨た，各測定項目は，負荷開始 後 4 分目および 8 分目の 1 分間の測定值をそれ ぞれ 2 METs および 4 METsでの定常状態にお ける測定値とした．動脈血がス分析は運動負荷 開始前と負荷終了後30秒以内に上腕動脈穿刺に て採血測定し，負荷終了後採血までに30秒以上 を要した例では測定值として採用しなかった。 また以上の負荷とは別に患者が $5 \mathrm{MET}$ s 以上の 負荷に耐えられるかどうかも検討した（図 1).

3）呼吸筋力の測定

呼吸筋力は千ェス卜社製呼吸筋力测定計バイ

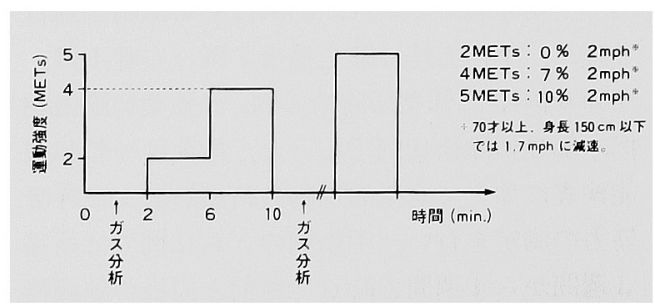

図 1 連動負荷試䮖の方法
タロパワーKH-101を用いて, 残気量位で最大吸 気努力をさせた際の口腔内圧を坐位にて測定し た. 測定は 3 回以上施行して，その最大值を最 大吸気圧 (Maximal Inspiratory Pressure : 以 下 MIP) として呼吸筋力の強さを評洒した，測 定は被験者が正確に残気量位で吸気に移れるよ うにするため，圧センサー部分に開けられた直 径約 $6 \mathrm{~mm}$ の通気孔を開放したまま，まずマウス ピースをくわえてゆっくり最大呼出させ，残気 量位になったところですばやく検者の指先で通 気孔を閉鎖して，そのまま吸気努力に移行でき るように注意した。

4) 術後 1 秒量の子測

術前に肺全摘術が予想される症例では術後の 残存肺機能の予測として ${ }^{99 m} \mathrm{Tc}-\mathrm{MAA}$ 肺血流シ ンチグラムを施行し, 左右別血流比を求めて, 術前 1 秒量に対側血流比を乗して術後 1 秒量予 測值とした。肺全摘術以外で注簡便法として次 の式にしたがって術後の予測値を計算した.

術後 1 秒量予測值 $=$ 術前実測 1 秒量 -

$$
\text { 術前実測 } 1 \text { 秒量 } \times \frac{\text { 切除区域数一閉塞区域数 }}{\text { 能を有する区域数 }}
$$

区域数は右肺10区域，左肺 9 区域とし，閉塞区 域は気管支ファイバースコピーの所見により判 定し, 気管支断面積の 4 分の 3 以上の閉塞所見 を認めた場合を閉塞区域とした。また部分切除 術は 1 区域切除として計算した。域枝以上の 気管支の閉塞を認めない末梢型の腫瘍について は単純に全区域数に対する切除後残存区域数の 比を乗じて計算した。

5) 酸素搨取指数: Oxygen Uptake Index の設定

下の式に示すように酸素搨取能力の指標とし て, 1 秒量 $\left(\mathrm{ml} / \mathrm{m}^{2}\right)$ と 4 METs 運動負荷時の $\dot{\mathrm{VO}}_{2} / \dot{\mathrm{VE}}(\%)$ の積を酸素掑取指数 Oxygen Uptake Index（以下 OUI と略す）と定義し, 術前運動能力との関係を検討した。また同様に， 術後 1 秒量予測値之術前の $4 \mathrm{METs}$ 運動負荷時 の $\mathrm{VO}_{2} / \dot{\mathrm{VE}} の$ 積を予測酸素攝取指数 predicted OUI と定義し,これと術後心肺合併症発生との 関係を検討した。 $\mathrm{OUI}=\mathrm{FEV}_{1,0}\left(\mathrm{ml} / \mathrm{m}^{2}\right)$ $\times 4 \mathrm{METs}$ 負荷での $\dot{\mathrm{VO}}_{2} / \dot{\mathrm{VE}}(\%)$ 
predicted $\mathrm{OUI}=$ 術後 $\mathrm{FEV}_{1.0}$ 予測值 $\left(\mathrm{ml} / \mathrm{m}^{2}\right)$ $\times 4 \mathrm{METS}$ 負荷での $\dot{\mathrm{VO}}_{2} / \dot{\mathrm{VE}}(\%)$

6) 術後心肺合併症の基準

術後心肺合併症としては, 下記 6 項目とした。

(1) 胸部レ 線写真上に認められた無気肺

(2) $38^{\circ} \mathrm{C}$ 以上の発熱を伴う肺炎

（3）治療を要した不整脈

(4) 術後レスピレータ2 日以上使用の呼吸不 全

(5) 術後 Hugh-Jones IV 度以上の Respiratory cripple

（6）気管支ファイバースコピーによる気道吸 引を要した喀痰喀出困難

以上の基準により，手術例69例中，肺炎 2 例， 不整脈 8 例, 呼吸不全 4 例, Respiratory cripple 2 例の計16例（手術例の $23.2 \%$ ）が合併症群と 判定された。検查デー夕の平均値の差に関する 統計処理は，すべて Student $\mathrm{t}$ 検定を用いて行 った.

\section{結果}

1. 呼吸困難度と運動能力の関係

術前および術後の自覚的呼吸困難度（HughJones 分類）とトレッドミルによる運動能の関 係を表 1 に示す。術前の運動負荷試験では自覚 的呼吸困難を感じない群 (Hugh-Jones 分類 I 度）では61例中57例 (93.4\%) で5 METs 以上 の運動が可能であった. Hugh-Jones 分類II 度の 群では 4 METsが最大運動能力であったものが 5 例，5METs 以上可能であったものが 6 例で あった. Hugh-Jones 分類 I 度で最大運動能力が 2 METsの症例が 1例あったが, これは日常生
活の運動程度が殆ど屋内のみと極めて低いため に，患者が呼吸困難を自覚する程度に至らなか ったものと考えられた。 また, Hugh-Jones 分類 III度の 1 例では 2 METs が最大運動能力であっ

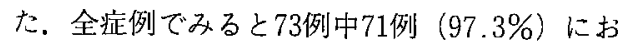
いて 4 METs 以上の運動に耐之られた. 一方， 術後に運動負荷試験を施行した45例において同 様に分類してみると,Hugh-Jones 分類 I 度では 術前と同様に $5 \mathrm{METs}$ 以上可能のものが多かっ たが, Hugh-Jones 分類 II 度およびIII度のもので は，その運動能力は 2 METs から 5 METsの間 に幅広く分布していた。

2. 運動負荷による $\dot{\mathrm{VO}}_{2} / \dot{\mathrm{VE}} の$ 変化（術前）

連動負荷による酸素利用率 $\dot{\mathrm{VO}}_{2} / \dot{\mathrm{VE}}$ を 5 METs まで測定した18例での結果を图 2 に示し た. 立位安静時において $\dot{\mathrm{V}} \mathrm{O}_{2} / \dot{\mathrm{VE}}$ は $1.77 \%$ から $3.22 \%$ までの範囲に分布し， 2 METs の運動に よって全症例で図のように増加したが，さらに 運動強度が増加して 4 METsになると4例で減 少傾向に転じ， $5 \mathrm{METs}$ になると新たに 5 例で 減少に転じた。立位安静時の値を100として18例 全体の平均值の変化を見ると, 図 2 の右に示す ように 4 METs で135.3土14.6\%とピークを示し， 5 METsでは134.7士13.4\%とわずかに減少傾向 となった。

3. 一酸化炭素应散能と運動時酸素利用率との 相関

術前の $4 \mathrm{METS}$ での $\dot{\mathrm{VO}}_{2} / \dot{\mathrm{VE}}$ と安静時にお ける一酸化炭素搪散能 DLco/VA との相関程度

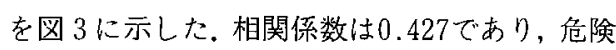
率 $1 \%$ 以下で有意の正の相関関倸が認められる ものの相関は良好とは言い難い。特に DLco/VA

表 1 術前, 術後の自覚的呼吸困難度 (Hugh-Jones 分類) と運動耐容能

術 前

\begin{tabular}{|c|c|c|c|c|}
\hline${ }_{\mathrm{H} \cdot \mathrm{J}}{ }^{\mathrm{METs}}$ & 2 & 4 & $5 \leqq$ & 計 \\
\hline I & 1 & 3 & 57 & 61 \\
\hline II & & 5 & 6 & 11 \\
\hline III & 1 & & & 1 \\
\hline 計 & 2 & 8 & 63 & 73例 \\
\hline
\end{tabular}

耐 後

\begin{tabular}{|c|c|c|c|c|c|}
\hline${ }_{\mathrm{H}-\mathrm{J}}$ & 2 & 3 & 4 & $5 \leqq$ & 計 \\
\hline I & & & 3 & 15 & 18 \\
\hline II & 2 & 2 & 4 & 10 & 18 \\
\hline III & 4 & 2 & 3 & & 9 \\
\hline 計 & 6 & 4 & 10 & 25 & 45例 \\
\hline
\end{tabular}



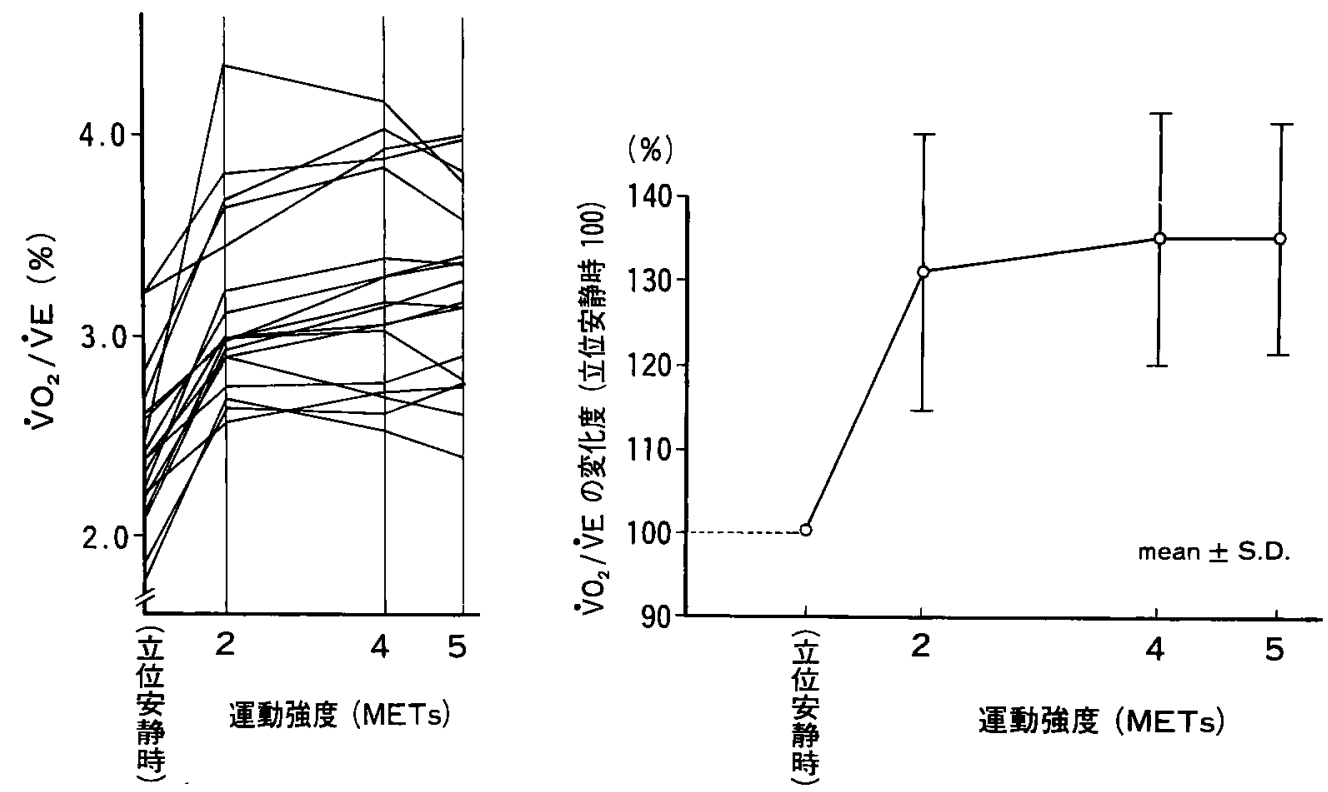

目 2 運動負荷による $\dot{\mathrm{VO}}_{2} / \mathrm{V} \mathrm{E} の$ 変化(術前, 18例)

が3.0以下の低值を示す症例では $\mathrm{VO}_{2} / \dot{\mathrm{VE}}$ も比 較的低い範囲にあるが, DLco/VAが3.0以上の 症例では $\mathrm{VO}_{2} / \dot{\mathrm{V} E}$ は広い範囲に分布する傾向が あった。

4. 術前の運動能力と測定値の検討

術前の最大運動能力が 4 METs の群をA群 $(\mathrm{n}=8), 5$ METs 以上の群を B群 $(\mathrm{n}=63)$ として両群の主な成績を表 2 おじ図 4 に示し た.

\section{1) 一般肺機能検查}

$\mathrm{FEV}_{1.0}$ はA群が $1091 \pm 381 \mathrm{ml} / \mathrm{m}^{2}$ に対して，B 群は $1452 \pm 348 \mathrm{ml} / \mathrm{m}^{2} て ゙$ 危険率 $1 \%$ 以下で両群に 有意差を認めた。 DLco/VA でもA群の3.09土

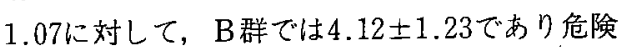
率 $5 \%$ 以下でやはり有意差を認めた。

\section{2) 運動急荷試験}

$4 \mathrm{METs}$ の運動負荷試験では $\dot{\mathrm{VO}}_{2} / \mathrm{VE} に お 3$ いてA群 $2.54 \pm 0.54 \%$, B群3.12 $\pm 0.42 \%$ と危 険率 $0.1 \%$ 以下で有意に $\mathrm{A}$ 群が低值を示し, 呼吸 数および呼吸商でもA群が有意に高値を示した。 しかし酸素消費量, 換気量, 心拍数, 酸素脈に ついては両群間で差を認めなかった，動脈血が ス分析の検討では，酸素分圧と炭酸がス分圧の 負荷前に対寸る負荷後の変化量をそれぞれ $\triangle \mathrm{PO}_{2}$

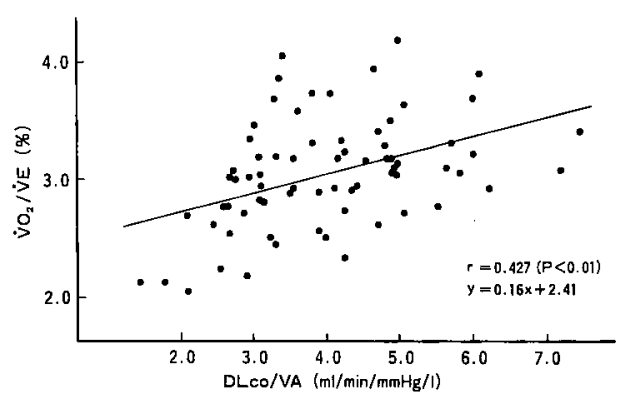

図 $3 \mathrm{DLco} / \mathrm{VA}$ と4METs 下の $\dot{\mathrm{V}} \mathrm{O}_{2} / \dot{\mathrm{VE}}$ の相関 関係 (術前, 71例)

および $\triangle \mathrm{PCO}_{2}$ として計算した. 測定値の有效例 数は $\mathrm{A}$ 群 7 例, $\mathrm{B}$ 群60例であったが, $\triangle \mathrm{Po}_{2}$ おうよ

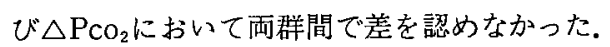

$\mathrm{A}, \mathrm{B}$ 雨群の $\dot{\mathrm{VO}}_{2} / \dot{\mathrm{V} E}$ の運動による変化を平 均值で検討すると, 図 5 に示したように安静時 にA群 $2.05 \pm 0.48 \% ，$ B群 $2.44 \pm 0.35 \%$ で既に 危険率 $1 \%$ 以下の有意差でA群が低值を示し, $2 \mathrm{METs}$ の運動強度ではA群 $2.57 \pm 0.59 \%, \mathrm{~B}$ 群3.08土0.41\%となり，4 METsになるとA群

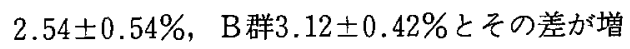
加し, 危険率 $0.1 \%$ 以下の有意差でA群が低値と なり, 運動強度が増加するほど両群間の差が大 
表 2 術前運動能力と肺機能検查, 運動負荷試験, 呼吸筋力

\begin{tabular}{|c|c|c|c|c|}
\hline & & $\mathrm{A}$ 群 $(\mathrm{n}=8)$ & $\mathrm{B}$ 群 $(\mathrm{n}=63)$ & 有意差 \\
\hline \multicolumn{2}{|l|}{ 年 跲 } & $71.8 \pm 6.9$ & $61.6 \pm 10.9$ & $P<0.05$ \\
\hline \multicolumn{5}{|l|}{ 一般肺機能検查 } \\
\hline \multicolumn{2}{|l|}{1 秒量 $\mathrm{FEV}$ 1.0 } & $1091 \pm 381$ & $1452 \pm 348$ & $P<0.01$ \\
\hline \multicolumn{2}{|c|}{$\mathrm{DLco} / \mathrm{VA} \quad(\mathrm{ml} / \mathrm{min} / \mathrm{mmHg} / \mathrm{l})$} & $3.09 \pm 1.07$ & $4.12 \pm 1.23$ & $\mathrm{P}<0.05$ \\
\hline \multicolumn{5}{|c|}{ 運動負荷試験 (4METs) } \\
\hline \multicolumn{2}{|c|}{ 酸素利用率 $\mathrm{VO}_{2} / \mathrm{VE}$} & $2.54 \pm 0.54$ & $3.12 \pm 0.42$ & $P<0.001$ \\
\hline \multicolumn{2}{|c|}{ 呼 吸 数 } & $34.8 \pm 8.1$ & $25.6 \pm 4.1$ & $P<0.05$ \\
\hline \multirow{2}{*}{ 酸素消費量 $\mathrm{VO}_{2}$} & $(\%)$ & $98.3 \pm 4.1$ & $94.1 \pm 5.2$ & $\mathrm{P}<0.05$ \\
\hline & $(\mathrm{ml} / \mathrm{kg} / \mathrm{min})$ & $16.3 \pm 2.9$ & $16.4 \pm 2.5$ & n.s. \\
\hline 換 気 量 VE & $\left(1 / \mathrm{m}^{2} / \mathrm{min}\right)$ & $23.1 \pm 6.4$ & $19.0 \pm 3.2$ & n.s. \\
\hline 心 拍 数 & (回/min) & $111.4 \pm 18.0$ & $108.0 \pm 14.9$ & n.s. \\
\hline 酸 素 脈 & $(\mathrm{ml} / \mathrm{HR})$ & $7.5 \pm 1.4$ & $8.4 \pm 1.9$ & n.s. \\
\hline$\triangle \mathrm{Po}_{2}$ & $(\mathrm{mmHg})$ & $8.4 \pm 9.2$ & $9.5 \pm 7.3$ & n.s. \\
\hline$\triangle \mathrm{PCO}_{2}$ & $(\mathrm{mmHg})$ & $0.3 \pm 4.8$ & $-0.1 \pm 2.9$ & n.s. \\
\hline \multicolumn{2}{|l|}{ 酸素㧺取指数 OUI } & $2664 \pm 830$ & $4475 \pm 1325$ & $\mathrm{P}<0.001$ \\
\hline \multicolumn{2}{|l|}{ 呼吸筋力 (MIP) } & $74.6 \pm 26.4$ & $108.4 \pm 40.6$ & $\mathrm{P}<0.05$ \\
\hline
\end{tabular}

$\mathrm{A}$ 群 : 最大運動能力 $4 \mathrm{METS} の$ 群

B群：" 5METs 以上の群

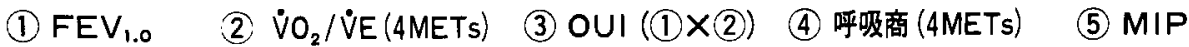

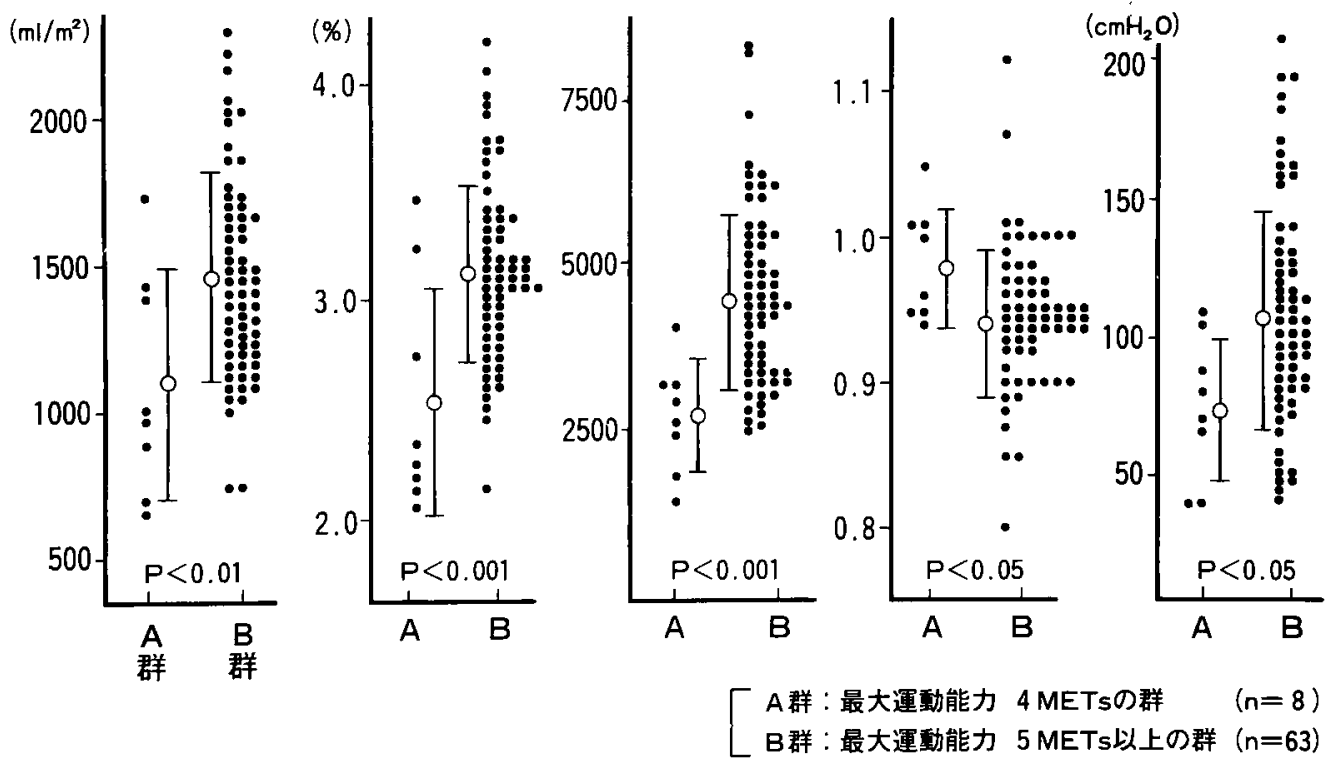

図 4 術前の運動能力と測定値（71例） 


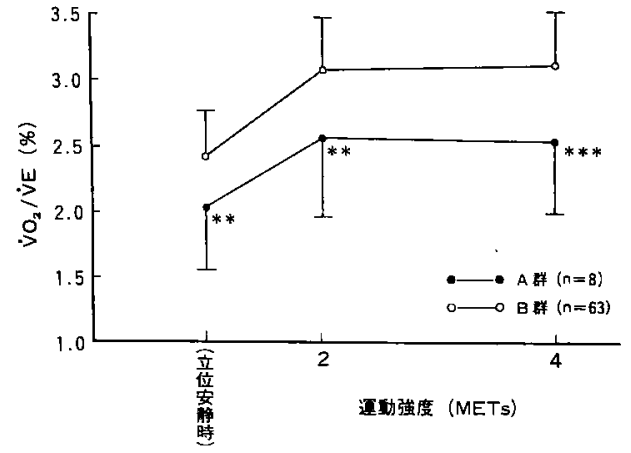

図 $5 \mathrm{~A}$ 样、B群における $\dot{\mathrm{V}} \mathrm{O}_{2} / \dot{\mathrm{VE}}$ の変化の比较 $* *: \mathrm{P}<0.01$

$* * *: \mathrm{P}<0.001$

きくなる傾向が見られた．1秒量と4METsで の $\dot{\mathrm{VO}}_{2} / \dot{\mathrm{VE}}$ の積である酸素攝取指数 OUI は $\mathrm{A}$ 群 $2664 \pm 830, \mathrm{~B}$ 群 $4475 \pm 1325$ と危険率 $0.1 \%$ 以 下で有意にA群が低值であり，図4 に示すよう に $\mathrm{FEV}_{1.0}$ や $\dot{\mathrm{VO}}_{2} / \dot{\mathrm{VE}}$ の分布に比較して両群間 の重なりが少なく，A群では比較的狭い範围に 集中した

3）呼吸筋力

呼吸筋力の指標である MIP においてもA群

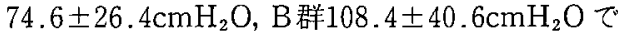
危険率 $5 \%$ 以下で有意差を認めた。両群間の分 布の重なりが多く見られたが，A群では全例110 $\mathrm{cmH}_{2} \mathrm{O}$ 以下であった。

5 . 術後合併症の有無と術前測定値の検討

合併症 (+) 群 $(\mathrm{n}=16)$ と合併症 ( （n=53）で，両群の術前の主な成績を表 3， 図6に示した。

\section{1）一般肺機能検查}

術後 1 秒量予測值は, 合併症 (十) 群が928土 $152 \mathrm{ml} / \mathrm{m}^{2}$ に対して合併症 (一) 群では $1288 \pm 322$ $\mathrm{ml} / \mathrm{m}^{2}$ であり，危険率 $0.1 \%$ 以下で両群に有意差 を認めた。しかし，DLco/VA は合併症群が低 值の傾向を示したものの有意差はなかった。

\section{2) 運動負荷試験}

$4 \mathrm{METs}$ の運動負荷試験では $\dot{\mathrm{VO}}_{2} / \dot{\mathrm{VE}}$ は合 併症 $(+)$ 群が $2.88 \pm 0.42 \%$ に対して合併症 $(-)$ 群では $3.13 \pm 0.43 \%$ で危険率 $5 \%$ 以下で両群に 有意差を認めた。呼吸数，呼吸商，酸素消費量， 換気量, 心拍数，酸素脈に関しては両群間で有
意の差を認めなかった．動脈血がス分析の検討 では, 測定值の有効例数は合併症 (+) 群50例, 合併症 (一) 群14例であったが, $\triangle \mathrm{PO}_{2}$ 抢よび $\triangle$ $\mathrm{PCO}_{2}$ において両群間で差を認好なった. 両群 の $\mathrm{VO}_{2} / \mathrm{VE} の$ 運動による変動を平均值で検討す ると,図 7 に示したように安静時には合併症 $(+)$ 群 $2.44 \pm 0.43 \%$, 合併症 (一) 群 $2.39 \pm 0.34 \%$ と殆んど差はないが，2METs 運動負荷時には 合併症 (十) 群 $2.91 \pm 0.46 \%$, 合併症 (-) 群 $3.07 \pm 0.43 \%$ と合併症 (+) 群が低值の傾向と なり，4METs 運動負荷になると合併症 $(+)$ 群 $2.88 \pm 0.42 \%$, 合併症 (-) 群 $3.13 \pm 0.43 \%$ となり危険率 $5 \%$ 以下で有意差を認めるように なった，predicted OUI を榆討すると図6に示 したように合併症（十）群では2595士397ですべ て3300以下の低い值に分布するのに対して，合 併症（一）群では $3770 \pm 1214$ と幅広く分布し危 険率 $0.1 \%$ 以下で有意差を認めた。

\section{3）呼吸筋力}

MIP は合併症 (一) 群では $111.8 \pm 39.4 \mathrm{cmH}_{2}$ ○であったのに対し，合併症 $(+)$ 群では79.7土 $32.9 \mathrm{cmH}_{2} \mathrm{O}$ であり，危険率 $1 \%$ 以下で有意に低 值を示した。合併症 (+) 群においては右肺全 摘術の1例を除いて全例 $110 \mathrm{~cm}_{2} \mathrm{O}$ 以下の値を 示していた。

4 ）術後合併症発生の予測について predicted OUI の值を横軸に, MIP の值を縦 軸にとり，合併症発生と測定值の関係を検討し た(図 8). predicted OUI が3300以下で MIP が $110 \mathrm{cmH}_{2} \mathrm{O}$ 以下の範囲にあるグループでは術 後合併症が多発していた。この範囲のグループ をRisk (+) 群，これ以外を Risk (一) 群と $し て$, retrospective に合併症発生との関係を検 討，判別した結果を表 4 に示した. Risk（+） 群の合併症発生率は51.7\% (15/29), Risk (-) 群の合併症非発生率は $97.5 \%(39 / 40)$ であった。 Risk の有無と合併症発生の関係はカイ二乗検定 において危険率 $1 \%$ 以下で有意の関係があり， 全体としての的中率は78.3\%(54/69)であった。 6. 手術による $\dot{\mathrm{VO}}_{2} / \dot{\mathrm{VE}}$ の変化について 術後にも運動負荷試験を施行した45例中，4 METs 以上の運動負荷に耐之られた35例におい て術後の運動負荷による $\dot{\mathrm{VO}}_{2} / \dot{\mathrm{VE}} の$ 変化を術前 
表 3 術後合併症と肺機能検查, 連動負荷試駘, 呼吸筋力

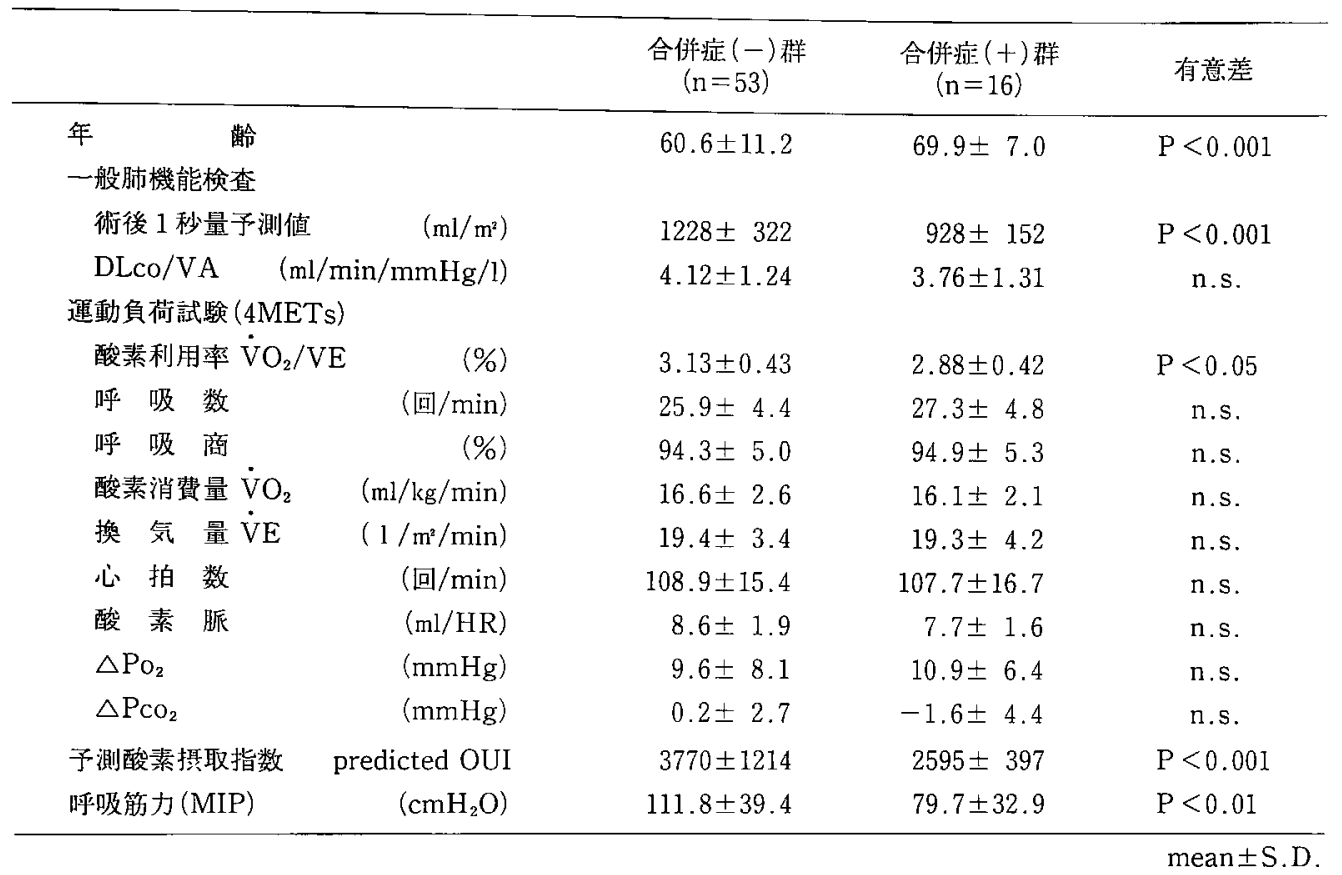
(1) 術後FEV 1.0 予測値
(2) $\dot{\mathrm{VO}}_{2} / \dot{\mathrm{V} E}(4 \mathrm{METS})$
(3) 予測 OUI (1) $\times(2)$
(4) MIP
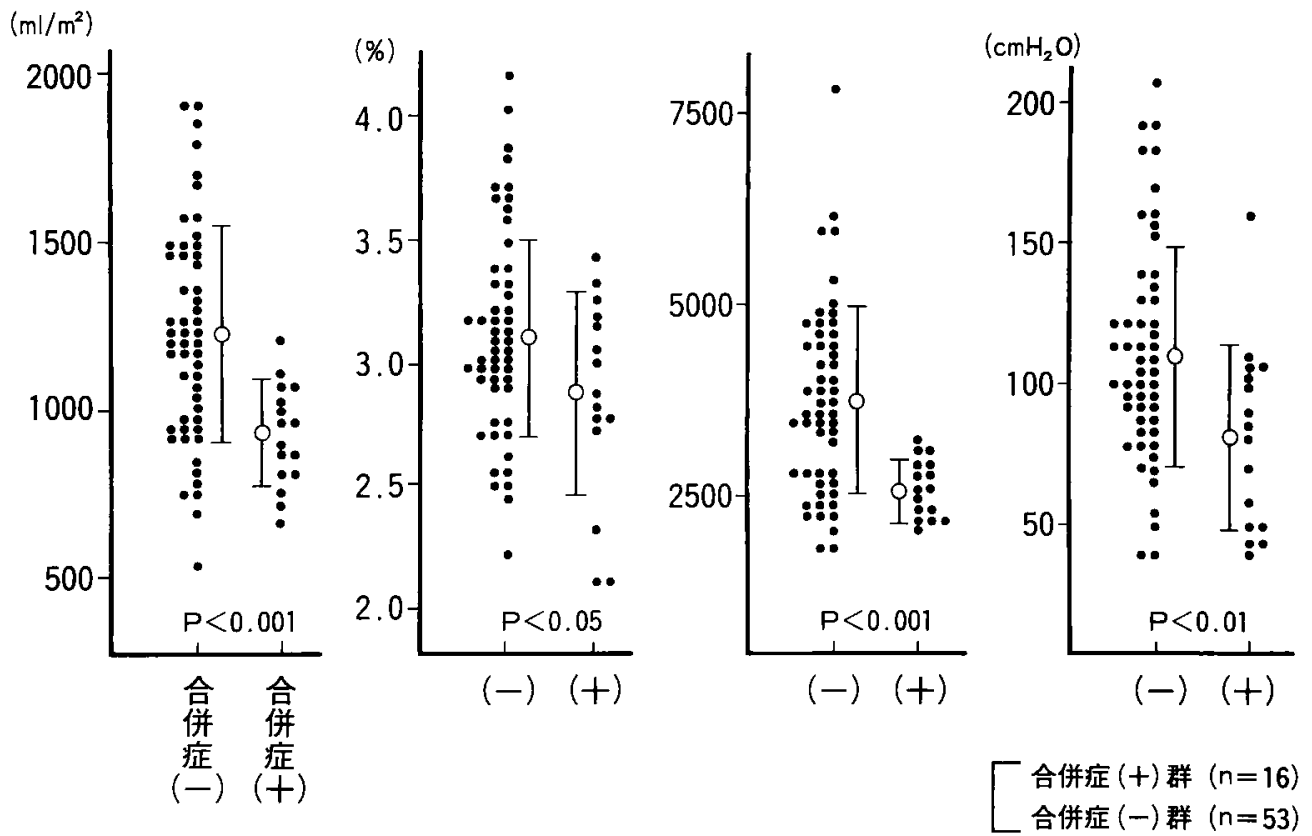

図 6 術後心湖合併症と测定值の関係（69例） 


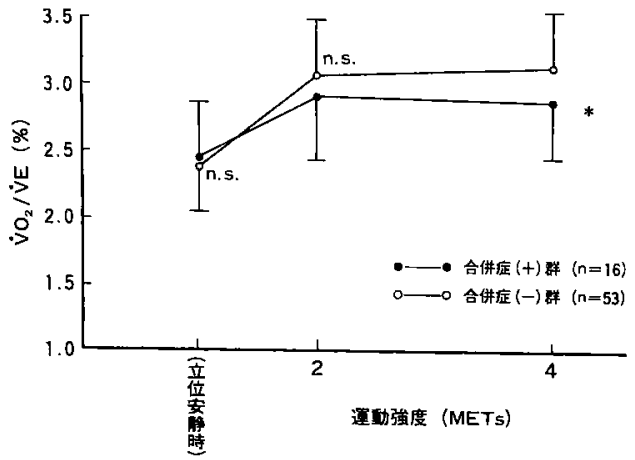

园 7 合併症 $(+)$ 群および(一)群における $\dot{\mathrm{VO}}_{2} / \mathrm{VE}$ の変化の比較

* : $\mathrm{P}<0.05$

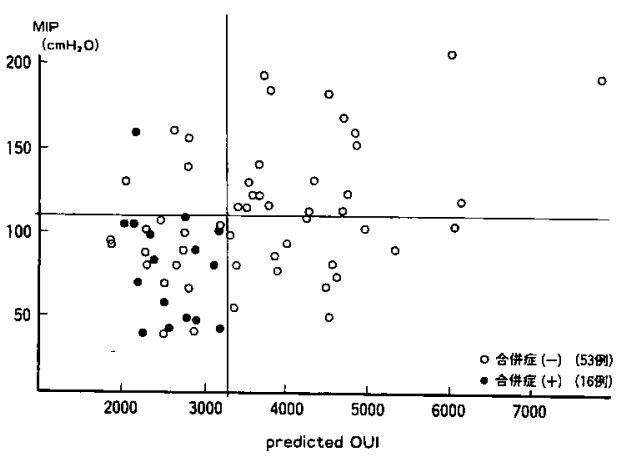

园 8 術後合併症と predicted OUI, MIP の関係

と比較した(図 9)。立位安静時においては術前 $2.40 \pm 0.37 \%$ ，術後 $2.41 \pm 0.30 \%$ とほとんど同 様の值を示したが，2METsの運動負荷時には 術前 $3.10 \pm 0.44 \%$ に対して術後は $2.88 \pm 0.36 \%$ と有意に低值となり，4 METs 連動負荷時には 術前 $3.16 \pm 0.42 \%$ に対して術後 $2.87 \pm 0.36 \%$ と さらにその差がわずかに增大した(危険率 $0.1 \%$ 以下)． 4 METs 運動負荷時における術前後の $\dot{\mathrm{VO}_{2}} / \dot{\mathrm{V} E}$ の相関を図10に示した。術後の值は術 前に比べて，平均で $0.29 \%$ 程度の低下傾向を示 していたが, 肺切除量による一定の傾向はなく， 相関関係は比較的良好であった（相関保数 $\mathrm{r}=$ $0.721, \mathrm{P}<0.01$ ).

\section{考}

肺切除術に際して，機能的な手術適応の決定 手段としては，歴史的に見てまず肺活量や 1 秒
表 4 術前 Risk と合併症発生における判別結果 (手術症例69例)

\begin{tabular}{cccc}
\hline & 合併症あり & なし & 合 計 \\
\hline RISK あり & 15 & 14 & 29 \\
\hline なし & 1 & 39 & 40 \\
\hline 合 計 & 16 & 53 & 69 例 \\
\hline
\end{tabular}

※ RISK あり : predicted OUI $\leqq 3300$ \& $\mathrm{MIP} \leqq 110 \mathrm{cmH}_{2} \mathrm{O}$

合併症発生の予測的中率：15/29（51.7\%）

合併症非発生の予測的中率：39/40 (97.5\%)

全体としての予測的中率：54/69 (78.3\%)

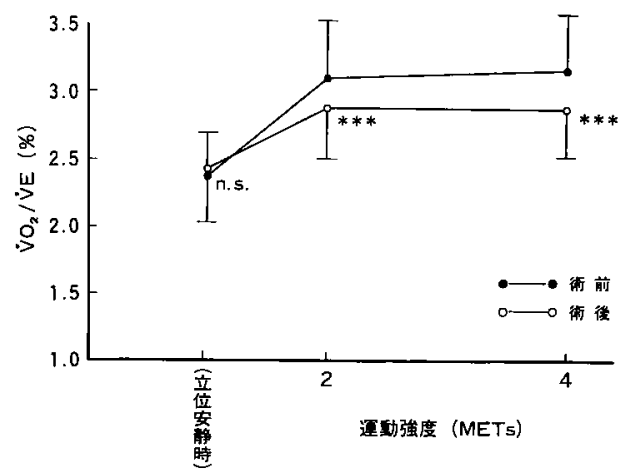

図 9 術前, 術後の $\mathrm{V}_{2} / \dot{\mathrm{VE}}$ の変化の比較 (35例) $* * *: \mathrm{P}<0.001$

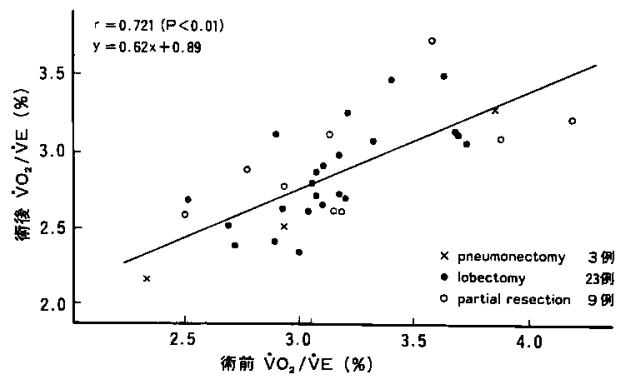

图10 4METs 運動負荷における術前後の $\mathrm{V}_{2} / \dot{\mathrm{VE}}$ (35例)

量を中心とした肺気量学的な許容限界が検討さ れ，続いて肺循環や心機能も総合的に評価しょ うとする目的で，運動負荷試験や右心カテーテ ル検查を用いた肺血管低抗の測定等が行われて きた，さらに最近では比較的新しい肺機能検查 
のパラメータとして呼吸筋力に関する検討も行 われている。運動生理学的には，現在のところ 最大酸素摂取能力が, 心肺系の総合的な予備力, いわゆる“体力”との相関が最も高いことが確立

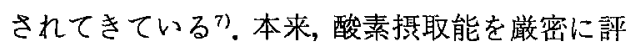
価する際には，溸增法による運動負荷により， 運動強度の増加に対して $\dot{\mathrm{VO}}_{2}$ がもはや増加を示 さない時点での $\dot{\mathrm{VO}}_{2}$ を $\mathrm{V}_{2} \max$ として捉える ことが必要であるが, 実際には被験者の symptom limited の時点での $\dot{\mathrm{VO}}_{2}$ を $\dot{\mathrm{VO}}_{2} \max と し て$ 代 用することが行われており，その値と術後合併 症あるいは手術死亡率の関係を検討した報告が 多(223)4). しかし, 肺癌を中心とする肺切除対象 患者では年々高齢化の傾向が著明となり，とく に75才以上の高踰者ともなると運動に対する意 欲低下傾向や検查に対する非協力性, あるいは 下肢の関節症等の身体局所的な問題により，こ のような方法で求められた酸素摂取能の值が真 の $\dot{\mathrm{V}}_{2} \max$ を反映しているかどうか疑わしい. しかるにむしろこのような症例に対してこそ， 心肺予備力を推定するための運動負荷試験が有 用であろうことが推測される，そこで今回，著 者は比較的高齢の集団である肺切除対象患者の 大部分が施行可能な程度の最大下 (submaximal）の定量的運動負荷試験を行い，その意義 を検討した。その結果, 運動強度としては，4 METs が適当であり，そのときの酸素利用率 $\dot{\mathrm{VO}_{2}} / \dot{\mathrm{VE}}$ が，患者評価に有用であると考えられ た. さらに 1 秒量や呼吸筋力と合わせて，総合 的に呼吸機能を検討することで，より適切な術 前患者評価が可能と思われた。

運動負荷試験の方法としては，呼気がス分析 を併用する場合にはトレッドミル法と自転車エ ルゴメータ法の2 種類の負荷方法が通常考之ら れるが, 運動負荷が最大負荷ではない点, 施設 間での運動強度の標準化がより容易な点を考慮 してトレッドミル法を採用した。本法において 異なる被験者に定量的な負荷量 (METs 数) を かける場合には，被験者間の体格の較差による 補正が問題となる．体重の差による酸素消費量 の補正に関しては， $1 \mathrm{~kg}$ 当たりの酸素消費量と して計算することでその影響は少なくなるが， 歩行運動の機械効率は単位時間当たりの歩数に
も影響され，歩幅の小さい高齢者や低身長の被 験者では同じ速度でも実際の負待量 (METs 数) は大きめになる傾向がある゙ . 実際, 欧米のトレ ッドミル歩行速度としてよく使われる時速 2 マ イルでは日本人の小柄な被験者では小走りに近 い状意となったり，また高齢者では転倒の危険 も実感したため，70才以上の高龄者および身長 $150 \mathrm{~cm}$ 以下の低身長者では歩行速度を1.7マイル に減少させて負荷量を調整した. 嚴密には Master の階段昇降負荷試験のように体格などで標準化 した運動負荷条件を個別に設定するべきかも知 れないが, 本研究では心筋虚血のような臟器不 全の徵候を検討するのではなく，運動により酸 素掑取効率を賦活するのが目的であり，上記の ような方法で十分であううと考えた。

術前73例の運動負荷試験では, 5 METs 以上 の負荷が可能であったものは63例 (86.3\%) で あり，4 METsが最大運動強度であった例が 8 例 $(11.0 \%)$ でこの両者で全体の $97.3 \%$ を占め ていた。すなわち 4 METsの負荷に耐之られな

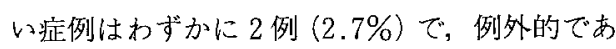
った。したがって対象患者集団の exercise performanceの程度のみから判断すると定量的運動

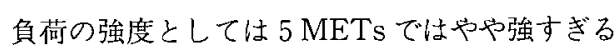
傾向があり，4 METs 以下が適当と考えられた。 $4 \mathrm{MET}$ Sの運動強度は自転車エルゴメー夕運動 の約50watts 程度に相当し, 一般健康人がレク レーションとして最も普通に行う程度のもので あり, 具体的にはゴルフや啌楽的球技, 庭仕事, 室内の清掃作業や柔軟体操等の運動強度であ る9. Bruce $^{10)}$ によると55才から64才までの非活 動的な成人の最大運動持続能力は平均 $6 \mathrm{METs}$ 前後ときれており，高齢者では $4 \mathrm{METs} の$ 運動 強度で既に嫌気性代謝閾值 (Anaerobic threshold，AT）に達している可能性が十分あると思 われた。

術前運動能力が 4 METs 以下の群（A群）と $5 \mathrm{METs}$ 以上の群(B群)の両群間で，4 METs の定量的運動負荷試験によって得られたパラメ 一夕のうち有意差を認めたものは, 酸素利用率 $\dot{\mathrm{V}} \mathrm{O}_{2} / \dot{\mathrm{VE}}(\mathrm{P}<0.001)$, 呼吸数 $(\mathrm{P}<0.05)$, 抒 よび呼吸商 $(\mathrm{P}<0.05)$ の 3 項目であり，これ らは，運動能力と相関があると考えられた。酸 
素消費量の数值は両群とも殆ど同じ平均值を示 し，有意差を認めなかった(表 2 )。一般肺機能 检查でも $\mathrm{A}$ 群は $\mathrm{B}$ 群に比べて 1 秒量および $\mathrm{DLco} / \mathrm{VA} に$ に扔いて有意に低值を示していた。 すなわち, 運動予備力の少ないA群においては, B群に比べて同程度の負荷でいわゆる“息のはず んだ”tachypneaの状態となる傾向が強く, 同程 度の $\dot{\mathrm{V}}_{2}$ の值でも, より䠫気性代謝の傾向が強 くなっていたと考えられた。

運動負荷時の $\dot{\mathrm{VO}}_{2} / \dot{\mathrm{V} E}$ は, 肺循環系の反応や 換気血流不均等分布の变化まで含めた心肺機能 をより適確に反映するであろうと考えられ，静 的な酸素掑取効率の指標である DLco/VAより も強い有意差で運動能力との相関が強かった. 運動負荷時の $\dot{\mathrm{VO}_{2}} / \dot{\mathrm{VE}}$ と安静時の $\mathrm{DLCO} / \mathrm{VA}$ の相関関係は図 3 で示したように必ずしも良好 ではなかったことから，前者の方が酸素摂取効 率の予備力をより反映し, 運動能力を評価する 指標として有用であると考之られた。また，心 肺合併症の有無により検討した結果でも，術前 の DLco/VA では有意差を認めなかったが， 4 METs での $\dot{\mathrm{VO}}_{2} / \dot{\mathrm{V} E}$ は, 合併症 (十). 群が合 併症 (一) 群に比べて有意に低値を示し $(\mathrm{P}<$ 0.05), 術後合併症発生の予測においても有用な パラメータと思われた。

運動負荷による $\dot{\mathrm{VO}_{2}} / \dot{\mathrm{V} E} の$ 増加程度を観察す ることは, 運動によって賦活された酸素掑取効 率を測定すると考えられ，呼吸の質的予備力の 評価として有用と思われる。運動時の $\dot{\mathrm{VO}}_{2} / \dot{\mathrm{VE}}$ を $\dot{\mathrm{VO}_{2} \max }$ そのものと直接関連づけることは

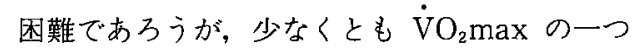
の決定因子としての役割を担うであろうことは， 容易に推測されるところであり, 最大運動能力 や $\dot{\mathrm{VO}}_{2} \max と \dot{\mathrm{VO}}_{2} / \dot{\mathrm{V} E} の$ 関連性についての研 究が報告されている。穈川ら ${ }^{11} は$, 一般外科手術 対象患者にエルゴメー夕渐增負荷を行い, 予借

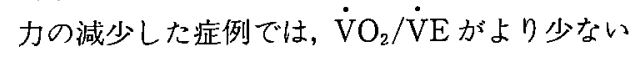
運動量で低下傾向を示すことを認め，その理由 として，そのような症例では $\mathrm{VO}_{2}$ の低い時点で

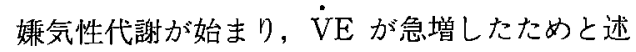
べている.また, 五味淵ら ${ }^{(2)}$ は肺切除術前㧍よび 術後患者に対してエルゴメータ潮增負荷法を行 い, 最大運動能力 (最大 METs 值) と $\dot{\mathrm{VO}}_{2} / \dot{\mathrm{VE}}$
が最大を示す時点の METs 值の間に $\mathrm{r}=0.682$ で比較的良好な相関関係を認めており, $\mathrm{VO}_{2} / \dot{\mathrm{VE}}$ の有用性を示唆している。これらの報告は，い ずれも渐増負荷試験による $\dot{\mathrm{VO}}_{2} / \dot{\mathrm{VE}}$ の変化のパ ターンを評洒しており,本研究のように, $4 \mathrm{METs}$ という単一段階の運動負荷時における $\dot{\mathrm{VO}}_{2} / \dot{\mathrm{VE}}$ の值そのものの有用性について検討した報告は ない.

$4 \mathrm{MET}$ という運動強度は，対象㭧者の大部 分が签易に完遂可能な最大の負荷量と考えられ， $4 \mathrm{METs}$ よも低い運動強度での $\mathrm{VO}_{2} / \dot{\mathrm{VE}} の$ 測定では, 術前運動能力や術後合併症発生の検 討において，有意差を示さなかった。すなわち， 運動強度の增加にともなって $\dot{\mathrm{VO}}_{2} / \dot{\mathrm{VE}} の$ 予備力 の差が表れたと考えられた。また, $\mathrm{VO}_{2} / \dot{\mathrm{VE}} の$ 変化を18例で測定した結果でも, $\mathrm{VO}_{2} / \dot{\mathrm{VE}}$ がピ 一クを示した運動負荷強度は個々の症例によっ て異なるが, 全体の平均としては $4 \mathrm{METs}$ でほぼ プラトーとなり，5METsではむしろ僅かに低 下傾向を示し，4 METs から $5 \mathrm{METS} \mathrm{までに}$ $\dot{\mathrm{V}} \mathrm{O}_{2} / \mathrm{VE}$ が最大を示寸症例が多いと考之られた。

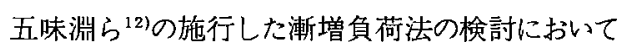
も $\dot{\mathrm{V}}_{2} / \dot{\mathrm{VE}}$ が最大を示した時の METs 值は概 ね 5 METs 以下に分布しているようであり，こ の点においても $4 \mathrm{METS} の$ 運動強度は適当と考 えられた。

運動に伴い, 肺拡散能力あるいは $\dot{\mathrm{VO}}_{2} / \dot{\mathrm{VE}}$ が 増大することはよく知られているが，さらなる 負荷の增加に伴い, $\dot{\mathrm{VO}}_{2} / \dot{\mathrm{VE}}$ がピークを示した 後に低下する機序は，一般には娥気性代謝の発 動により, $\dot{\mathrm{VE}}$ が $\mathrm{V}_{2} に$ 对して相対的に増加する ことが主因と考えられている.しかし，心肺予 備力の低下した患者では, $\dot{\mathrm{V}}_{2} / \dot{\mathrm{VE}}$ 低下の原因 として呼気性代謝だけでなく, 肺内 $\dot{\mathrm{V}}_{\mathrm{A}} / \dot{\mathrm{Q}}_{\mathrm{C}}$ 不 均等分布の増恶や，肺胞気と肺内毛細管血の接 触時間の短縮などによることも考えられている13). $4 \mathrm{METS}$ 以下の運動強度でこのような理由で

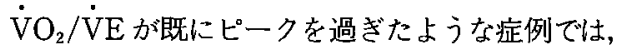

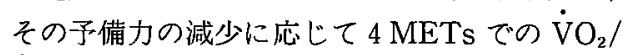
VE が最大值よりも低如評洒されると考えら れ，肺実質の予備力の低下を反映すると思われ た。すなわち，4 METsの単一段階運動負荷に

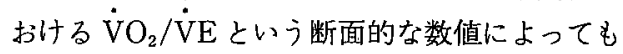


酸素摂取効率の potential を良好に評価できる ものと考えられた。

一方， 1 秒量や術後 1 秒量子測值は術前に耐 術能を予測する最も簡単で比較的確実な指標と して应く利用されている。今回の結果でも術前 1 秒量と術後 1 秒量予測値はそれぞれ術前運動 能力と術後合併症発生に関して有意の平均值の 差が認められた。そこで, 呼吸の量的予備力の 指標である 1 秒量 $\left(\mathrm{ml} / \mathrm{m}^{2}\right)$ と, 質的な予備力の 指標と考えられる 4 METs での $\dot{\mathrm{VO}}_{2} / \dot{\mathrm{VE}}(\%)$ (以下 $\dot{\mathrm{VO}}_{2} / \dot{\mathrm{VE}} / 4 \mathrm{METs} と$ 表す) を総合的に 表す方法として，この両者の積を酸素摂取指数 OUI と定義したが, OUI は, この定義から考之 て, $\mathrm{VO}_{2} \max$ を仮想的に表現する指数と解釈し た. OUI と $\mathrm{VO}_{2} \max と の$ 関係は直接には証明 しなかったが, OUI と術前運動能力との関係を 検討したところ,この数值は 1 秒量や $\dot{\mathrm{VO}}_{2} / \dot{\mathrm{VE}} /$ $4 \mathrm{METs}$ 単独に比べて運動能力とより良好な相 関性を示し, $4 \mathrm{METs}$ が最大運動能力である群 （A群）では，より低值の狭い範团に集中した (図 4). .さらに術後合併症の発生を検討する際 に，肺切除量を考慮に入れて predicted OUI を 定義した。術後の1秒量は計算により予測可能 であるが, 術後の $\dot{\mathrm{VO}}_{2} / \dot{\mathrm{VE}} / 4 \mathrm{METS}$ の值を予 測することは，実際上困難と考えられたので， 計算には術前值をそのまま使用した。実際の測 定結果でも図10に示すように, 術後の $\dot{\mathrm{VO}}_{2} / \dot{\mathrm{V} E} /$ 4 METsの値は術前值にくらべてやや低値を示 す傾向があるが,切除量との相関は認められず， 術前值と比較的良い相関性を示しており（ $\mathrm{r}=$ $0.721)$, 肺切除によっても残存肺自体の酸素捸 取の質的特性には大きな変化はなく, 術前值を よく反映すると考えられた。したがって, predicted OUI の計算に際して術前の $\mathrm{VO}_{2} / \mathrm{VE} / 4 \mathrm{METs}$ の值を使用しても差し支えないと考えられた。 このようにして計算した predicted OUI と術後 合併症との関係を検討した結果, predicted OUI は術後 1 秒量子測值や $\dot{\mathrm{VO}} \mathrm{O}_{2} / \mathrm{VE} / 4 \mathrm{METs}$ 単独 に比へて合併症発生により強い関係を示し，そ の数值は合併症 (十) 群では3300以下の狭い範 囲に集中して㧈り，合併症発生予測の指標とし ても有用であると教えられた(四6)。於 $\mathrm{O}_{2} \max$ を直接測定することなく，最大下の運動負荷で
$\dot{\mathrm{V}} \mathrm{O}_{2} \max$ 間接的に推定する方法はいくつか報 告されている。よく知られた方法は, 心拍数が $\mathrm{V}_{2}$ とほぼ直線関倸を示すと仮定し, 一定負侍下 の心拍数と $\mathrm{VO}_{2}$ の测定値から, 予测最大心拍数 における $\mathrm{VO}_{2}$ を外雨法や推定式により求め, $\dot{\mathrm{VO}}_{2}$ $\max$ とする方法である ${ }^{14)}$ このような方法では, 心肺機能の個人差を考之ず予測最大心拍数を性， 年齢から計算式によって機械的に求めることな どに問題があると考えられ，特に心肺疾想や筫 血等の症例では誤差が大きいことが指摘されて おり ${ }^{15)}$,一般的に使用されているとは言い難い。 また, Bruce ら (6)は漸増負荷法における運動持 続可能時間により $\mathrm{VO}_{2} \max$ を推定する式を求め, 実測値と良い相関性があるとしたが，再現性に 問題があること，また日常の身体活動レベルに よって推定值が規定されるなどの問題があると

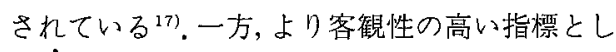
$て \dot{\mathrm{V} O}{ }_{2} \max$ とは別に婔気性代謝閾值 anaerobic threshold (AT) を测定して酸素攝取能を評価し ようとする方法 ${ }^{18)}$ も理論的には優れた方法である. しかし, 現在行われているような呼気がス分析 あるいは血中乳酸值から A Tをもとめる方法で は，血中乳酸值や $\dot{\mathrm{V} E}$ の增加が $\mathrm{VO}_{2}$ の增加に対 して，必ずしもATとしての明暸な変曲点を示 さない場合も多いとされており ${ }^{199}$,全症例におい てATを適確に決めることは困難と考えられて いる.

本研究において考案した OUIによる酸素捸取 能力の推定では, 直接 $\dot{\mathrm{V}} \mathrm{O}_{2}$ を测定するのではな く，呼吸の量的な予備力を表すと考之られる指 標 (1 秒量) と, 質的な予備力を表すと考之ら れる指標 ( $4 \mathrm{METs}$ での $\left.\dot{\mathrm{VO}}_{2} / \dot{\mathrm{VE}}\right)$ をそれぞれ 独立に測定し，その皘を用いて仮想的な $\mathrm{VO}_{2} \mathrm{max}$ ともいうべき数值を計算した。このようにして 計算したOUI 用いて実際に肺切除の評檤をす る際には, 術後 1 秒量予測值が良好な值でも $\dot{\mathrm{V}}_{2} / \mathrm{VE} / 4 \mathrm{METs}$ が低い值を示せば, その数值 に影響され predicted OUIは比較的低值となり， 術後 1 秒量予測值が不良な值でも $\dot{\mathrm{VO}}_{2} / \dot{\mathrm{VE}} / 4$ METs が高い值であれば, predicted OUIは， さ汪ど低值とならない。したがって，従来主と して行われてきた1秒量を中心とした肺気量に より耐術能を評佂するよりもより優れた耐術能 
の予測結果が得られるものと考之られた。本法 の特徵は，まず愳者に最大運動負荷をかけるこ となく，一般肺機能検查と極めて簡単な単一運 動負荷により評価できること，また肺切除の際 にも predicted OUI として切除量に応じた数值 を求めることにより，比較的簡単に耐術能の評 洒に芯用できる点であろう。本研究と同様に非 等度の単一段階運動負荷試験で耐術能を推定し ようとした研究では, Olsen ら ${ }^{5}$ が, 閉塞性肺障 害の術前患者にエルゴメータで40watts(約 3〜4 METsに相当) の運動負荷をかけた結果, 耐術

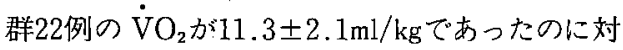
して, 非耐術群 7 例では $7.8 \pm 1.5 \mathrm{ml} / \mathrm{kg}$ で有意差 を認めたと述べている。しかし，かれらの対象 とした症例は, 本研究とは異なり, 予備力の少 ない比較的高度の閉塞性障害の群であったため に, 40watts 程度の負荷で非耐術群では既に $\dot{\mathrm{V} O}{ }_{2}$ maxに達していたのではないかと考えられ，通 常の肺手術患者を対象とした本研究とは，異な った結果が得られたものと考えられた.

呼吸筋力の測定方法については最も簡便で再 現性の良いと思われる方法で測定した。すすな ち MIPはMEPに比べて，測定方法によるばら つきが小さいと考えられており20)，是らに吸気努 力時のほうが呼気努力時に比べて声門閉鎖や煩 筋の影響を受けにくいと考えられた。また著者 の施行した方法，すなわちマウスピースをくわ えたまま残気量位までゆっくりと呼出していき， そのまま最大吸気努力に移行する方法では，残 気量位まで呼出してからのちにマウスピースを くわえる方法に比べてより確実に肺気量の調節 が可能であり，高齢者でも容易に行之る方法と 考之られた。声門閉鎖や頓筋筋力の影響を除外 するためにマウスピース部に small air leak を 設けることは Ringqvist の報告 ${ }^{21}$ 以来, 広く行 われているが，今回の測定ではより厳密に残気 量位での吸気努力が維持できるようにと考え， leak を設けずに施行した。 leakの有無は MIP の測定値に影響しなかったという Smyth ら ${ }^{221} の$ 報告もあり，この問題は測定時に患者が正しく 呼吸筋によって吸気努力しているかどうかを注 意深く観察することで解決できると考えた。呼 吸筋力の検討においては，現在までに主として
神経筋疾患や慢性閉塞性肺疾患等での評洒が行 われてきた 23124).外科手術と関連した報告では， 小池ら ${ }^{25}$ が, 外科手術術前患者の咳嗽力の指標と して咳嗽時最大呼出流量を測定し，それが，最 大呼気口腔内压 (MEP) と正の相関性があるこ とを示し, 呼吸筋力の低下が去痰困難等の術後 合併症の一因になる可能性を示唆している。 ま た，肺手術と関連づけて検討された報告では， 安藤 20 が肺癌手術患者で詳細に呼吸筋力を検討 し，換気の generator として測定の重要性を強 調したものがあるが，実祭に，術前の評洒項目 として呼吸筋力と肺手術合併症との関連を調べ た報告は少ない。

呼吸筋力の正常值としては，各報告者によっ て，測定方法や対象の違いによると考之られる 多少のばらつきがあるが，男性は女性よりも高 值で加龄により低下寸る傾向があり ${ }^{26)}$, 健常成人 男性の MIP の平均で100から $125 \mathrm{cmH}_{2} \mathrm{O}$ 程度の 報告が多い20).しかし分布の範囲は, 正常健康人 を対象とした報告でも MIP が50から $200 \mathrm{cmH}_{2}$ $\mathrm{O}$ 程度と正常值の範囲が極めて大きいのが特徵 であり 27228)，今回測定した肺手術術前患者でもこ れらの数值と近似していた. 安藤 ${ }^{20} の$ 報告では, 肺癌患者の正常肺機能群では MIPは骨格筋の 筋力である握力と $\mathrm{r}=0.69$ で比較的良好な正の 相関関係を示しており，むしろ肺機能そのもの よりも骨格筋筋力と良い相関を認めている。そ のほか，栄盖状態や体格との相関性も報告され ており ${ }^{29330)}$ 、いずれにしても多数の因子の影響を 受けることは確実であろう。また，MIPがある 程度まで低下していても，肺活量等の肺気量に は殆ど影響しないとされておりぶ1)，その意味では 肺気量よりも敏感な指標といえる。しかし, MIP の值そのものは，換気運動の driving power を 反映するものと考えてよく, 最大換気量 $\mathrm{MVV}$ は 1 秒量の他に MIPに影響されるという27/30). $\mathrm{Mittman}^{322}$ は胸部手術の際に, 一般肺機能検查 の中では MVV が耐術能の決定にもっとも優れ た指標であると考えているが,これは MVVが 肺気量と呼吸筋力の両者を, ある程度総合的に とらえているためとも考えられた。

今回の著者の検討では, 術前の運動能力の優 劣で分類した 2 群間と, 術後心肺合併症の有無 
により分類した 2 群間とで，それぞれ共に MIP の平均値に有意差を認めた。すなわち，術前の 最大運動能力が 4 METsに制限されていた群お よび術後心肺合併症を発生した群では右肺全摘 の1例を除いて，すべて MIP が $110 \mathrm{cmH}_{2} \mathrm{O}$ 以 下であった。この110 $\mathrm{cmH}_{2} \mathrm{O}$ という值は偶然に も諸家の報告した平均値に近い值である。しか し, 術前の最大運動能力が 5 METs 以上の群や 術後合併症の見られなかった群においても MIP が110 $\mathrm{cmH}_{2} \mathrm{O}$ 以下である症例のほうが $110 \mathrm{cmH}_{2}$ $\mathrm{O}$ 以上の症例上りも多数を占めて扔り, MIPが 低值であることの意義よりも，むしろ MIP が 平均值よりも高值であることの意義，すなわち $110 \mathrm{cmH}_{2} \mathrm{O}$ 以上の強い呼吸筋力のある症例では 通常の運動能力を認め, な扰術後合併症発生の リスクが少ないと考えられたことの方が重要で あると思われた。

肺手術術前患者を評価する際に，肺という臓 器を酸素を搨取する一つの取り込み型のポンプ と仮定して考えると, 肺活量や 1 秒量に代表き れる肺気量学的なパラメー夕はポンプの量的な 予備力の一面のみを捕らえているに過ぎない． ポンプ全体の予備力の評価には肺循環も含めた 質的な酸素取り込みの効率や機械的な換気の駆 動力をも考慮に入れる必要があると考之られた。 Dillard ら ${ }^{61}$ は閉塞性肺疾患患者20例で揮動負荷 試験と呼吸筋力の測定を行い, $\mathrm{VO}_{2} \max は 1$ 秒 量, 拡散能力, 最大吸気筋力の 3 つの測定值か ら得られる回帰式でよく近似されたとし，これ らの3つの值はそれぞれ conducting airways, pulmonary parenchyma, chest wall $の$ 構成成 分の機能を表すと述べて，やはり，これら肺機 能の量的, 質的な要素と換気駆動力の 3 つを重 視している。そこで量的予備力のパラメータと して 1 秒量, 質的予備力のパラメータとして $\dot{\mathrm{VO}}_{2} /$ $\dot{\mathrm{VE}} / 4 \mathrm{METs}$, そしてポンプ自体の換気駆動力の 予備力のパラメータとして呼吸筋力 (MIP) の 3 者をいわばポンプの 3 大要素ともいうべき重 要なパラメータと仮定した。これら 3 つのパラ メータの相関関係を図11に示した。1 秒量と $\dot{\mathrm{VO}_{2}} / \dot{\mathrm{VE}} / 4 \mathrm{METs}$ との相関係数は $\mathrm{r}=0.164$ と 極弤值であり有意の相関関係は認めなかっ た. MIPと 1 秒量および $\dot{\mathrm{VO}} 2 / \dot{\mathrm{VE}} / 4 \mathrm{METS}$ と

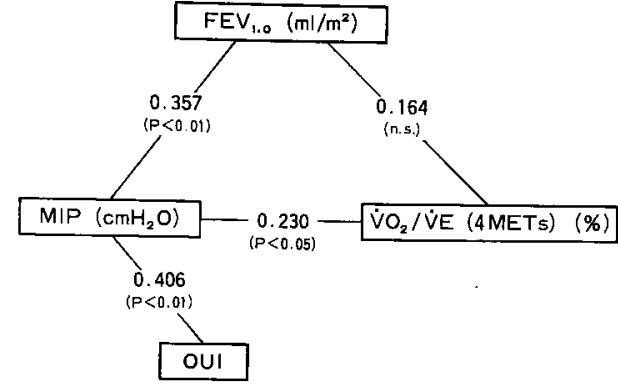

図11 $\mathrm{FEV}_{1.0}, \mathrm{MIP}, \dot{\mathrm{V}} \mathrm{O}_{2} / \dot{\mathrm{VE}}(4 \mathrm{METs}$ )の相関(術 前, 71例)

の間には有意の正の相関関係を認めたが，相関 係数はそれぞれ $\mathrm{r}=0.357(\mathrm{P}<0.01)$ および $\mathrm{r}=$ $0.230(P<0.05)$ と比較的低值であった。患者 評価に際しては，それぞれに有用で，しかも独 立性の強い評価方法を組み合わせて検討するこ とが重要であり，これら 3 つのパラメータの相 関係数が小さいことはそれぞれの性格がお互い に異なっていることを示していると考えられた。 以上述べたような理論をもとに, 術後 1 秒量予 测値と $\mathrm{VO}_{2} / \dot{\mathrm{VE}} / 4 \mathrm{METS} の$ 積を predicted OUI と定義し，さらに MIPを組み合わせるこ とで術後合併症発生の予測を試みたところ，図 8 に示したように predicted OUI が3300以下で MIP が $110 \mathrm{cmH}_{2} \mathrm{O}$ 以下の症例で術後心肺合併 症が多発し，合併症発生の的中率が $51.7 \%$, 非 発生の的中率が $97.5 \%$ と比較的良好な結果が得 られた．合併症発生の予測の特徴は通常，一般 に非発生の予測は容易でも，発生の予測はやや 困難であることであるから，この成績は臨床応 用可能な満足すべき数值と考えられた．対象や 合併症の基準が報告ごとにやや異なるので単純 な比較はできないが, 運動負荷試験によって合 併症予測を行った肺切除症例における他の報 告 ${ }^{344}$ と比べても優るとも劣らない予測成績と思 われた. すなわち, 定量的単一強度の運動負荷 試験と呼吸筋力検查と一般肺機能検査の 3 者で 得られるパラメータを組み合わせることで，従 来の多段階運動負荷試験で行うよりも，より患 者の負担が少なく，簡単な力法で耐術能のより 適切な評価が可能であると考えられた。 


\author{
結 \\ 論 \\ 肺切除对象患者73例に対し，一般肺機能検查 \\ に加えて，術前にトレッドミルによる定量的運 \\ 動負荷試験拉よび呼吸筋力測定を施行した。 そ \\ のうち69例に肺切除術が施行され，45例につい \\ ては術後にも同様の運動負荷試験を施行した。 \\ 1. 定量的運動負荷試験の強度としては 4 \\ METs 程度が適当と考えられた。 \\ 2.4 METs の定量運動負荷試験に扔ける酸素 \\ 利用率 $\left(\dot{\mathrm{VO}}_{2} / \dot{\mathrm{VE}} / 4 \mathrm{METS}\right)$ は, 術前運動 \\ 能力が 4 METs までの群(A群)が 5 METs \\ 以上の群（B群）との群に対して有意に低 \\ 值であった（P<0.001）。また術後合併症 \\ （+）群では合併症（－）群に比べて有意 \\ に低值を示した $(P<0.05)$. \\ 3.MIPは, $\mathrm{A}$ 群が $\mathrm{B}$ 群よりも有意に低值を示 \\ した $(P<0.05)$. また, 術後合併症 $(+)$ \\ 群では合欮症 (一) 群に比べて有意に低值 \\ を示した $(\mathrm{P}<0.01)$. \\ 4. 酸素摂取指数 OUI は, A群では B 群に比へ
}

て低値に箱中し, 強い有意差を認めた $(\mathrm{P}<$ 0.001). また，予測酸素摂取指数 predicted OUI は, 術後合倣症 $(+)$ 群では合併症 $(-)$ 群に比べて低値に集中し, 強い有意差を認 めた $(\mathrm{P}<0.001)$.

5. predicted OUI が3300以下で, MIP が110 $\mathrm{cmH}_{2} \mathrm{O}$ 以下の症例では, 術後心肺合併症を 発生する可能性が高いと考之られ， $51.7 \%$ に術後合併症が発生した.

6. 1 秒量, $\mathrm{VO}_{2} / \dot{\mathrm{VE}} / 4 \mathrm{METs}$ MIP はそれぞ れ呼吸機能の量, 質, 力の予備力を反映す るパラメータと考えられ，この3 者を総合 的に檢討することにより，より適確な患者 評価ができる可能性が示唆された。

稿を終えるにあたり，ご指導ご校閲を賜った岡山大 学第 2 外科学教室, 寺本 滋教授に厚く御礼申し上 げます。また，值接ご指導いただいた教室の清水信 義誹師, 安藤陽夫先生に樑謝いたします。

本諭文の要旨は, 平成 2 年 5 月, 第 7 回日本呼吸 器外科学会総会 (東京)において発表した。

文

献

1) Olsen GN : The evolving role of exercise testing prior to lung resection. Chest (1989) 95, 218-225.

2) Smith TS, Kinasewits GT, Tucker WY, Spillers WP and George RB : Exercise capacity as a predictor of post-thoracotomy morbidity. Am Rev Respir Dis (1984) 129, 730-734.

3) Bechard D and Wetstein L : Assesment of exercise oxygen consumption as preoperative criterion for lung resection. Ann Thorac Surg (1987) 44, 344-349.

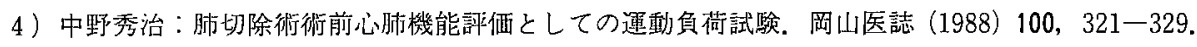

5) Olsen GN, Weiman DS, Bolton JWR, Gass GD, Mclain WC, Schoonover GA and Hornung CA : Submaximal invasive exercise testing and quantitive lung scanning in the evaluation for tolerance of lung resection. Chest (1989) 95, 267-273.

6) Dillard TA, Piantadosi $S$ and Rajagopal KR: Determinants of maximum exercise capacity in patients with chronic airflow obstruction. Chest (1989) 96, 267-271.

7) Mitchell JH and Blomqvist G: Maximal oxygen uptake. New Eng J Med (1971) 284, 1018-1022.

8 ) 外畑 㦑, 志野友義: Treadmill 運動負荷試験；循環器負荷試験法一理論と実際一, 水野康, 福田市藏 編, 診断と治療社, 東京 (1986) pp 219-249.

9 ）西邑信男：運動負荷試験のすす女，克誠堂出版株式会社，東京（1990）pp 26-32.

10) Bruce RA : Normal values for $\dot{\mathrm{VO}}_{2}$ and $\dot{\mathrm{VO}}_{2}$-HR relationship. Am Rev Respir Dis (1984) 129, S41 $-\mathrm{S} 43$.

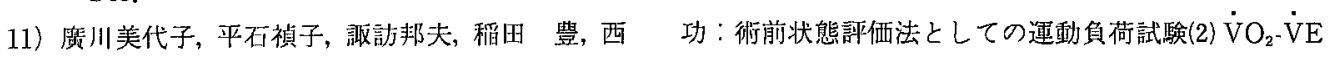
の反応を指標として。碄醉 (1985) 34，1237-1244. 
12）五味淵誠，田中茂头，松島伸治，小泉 潔，富上崎隆，原口秀司，福島孝男，庄司 佑：肺切除後の運動負 荷に上る呼吸機能の変化。日呼外会誌 $(1990) 4 ， 408-415$.

13）川城丈夫：スポーツと呼吸機能一脯のガス交鲃一。呼吸（1990） 9，1095-1102.

14) Margaria $R$, Aghemo $P$ and Rovelli $E$ : Indirect determination of maximal $\mathrm{O}_{2}$ consumption in man. J Appl Physiol (1965) 20, 1070-1073.

15) Davies CTM : Limitations to the prediction of maximum oxygen intake from cardiac frequency mesurements. J Appl Physiol (1968) 24, 700-706.

16) Bruce RA, Kusumi $F$ and Hosmer $D$ : Maximal oxygen intake and nomographic assessment of functional aerobic impairment in cardiovascular disese. Am Heart J (1973) 85, 546-562.

17) Froelicher VF Jr., Brammell HDG, Noguera I, Stwart A and Lancaster MC : A comparison of three maximal treadmill exercise protocols. J Appl Physiol (1974) 36, 720-725.

18) Wasserman $\mathrm{K}$, Whipp BJ, Koyal $\mathrm{SN}$ and Beaver WL : Anaerobic threshold and respiratory gas exchange during execise. J Appl Physiol (1973) 35, 236-243.

19）三好新一郎，門田康正，中原数也，肺癌患者における段階的運動負獄試敇。日胸疾会誌 (1986) 24，618一 624.

20）安藤陽夫：肺癌患者の呼吸筋力に関する臨床的研究。岡山医誌（1987）99，987-1001.

21) Ringqvist $T:$ The ventilatory capacity in healthy subjects. Scand J Clin Lab Invest (1966) 88(Suppl. 18), $1-179$.

22) Smyth RJ, Chapman KR and Rebuck AS : Maximal inspiratory and expiratory pressures in adolescents. Chest (1984) 86, 568-572,

23) Black LF and Hyatt RE: Maximal static respiratory pressures in generalized neuromuscular disease. Am Rev Respir Dis (1971) 103, 641-650.

24) Byrd RB and Hyatt RE : Maximal respiratory pressures in chronic obstructive lung disease. Am Rev Respir Dis (1968) 98, 848-856.

25）小池輝明，広野達彦，滝沢恒世，大和 靖，相馬孝博，吉谷克雄，中山健司，土田正則，江口昭治：肺澏術 後肺合併症一特に去痰困難と咳嗽力について一，日胸外会誌（1989）37，1889-1892.

26) Black LF and Hyatt RE : Maximal respiratory pressures: Normal values and relationship to age and sex. Am Rev Respir Dis (1969) 99, 696-702.

27) Lavietes MH, Clifford E, Silverstein FS, Stier F and Reichman LB: Relationship of static respiratory muscle pressure and maximal voluntary ventilation in normal subjects. Respiration (1979) 38, 121-126.

28) Girbert R, Auchincloss Jr. JH and Bleb S : Measurement of maximum inspiratory pressure during routine spirometry. Lung (1978) $155,23-32$.

29) Arora NS and Rochester DF : Respiratory muscle strength and maximal voluntary ventilation in undernurished patient. Am Rev Respir Dis (1982) 126, 5-8.

30) Leech JA, Ghezzo H, Stevens D and Becklake MR: Respiratory pressures and function in young adults. Am Rev Res Dis (1983) 128, 17-23.

31) Bates DV : Respiratory Function in Disease. WB Saunders Co., Philadelphia (1989) pp369-381.

32) Mittman C : Assesment of operative risk in thoracic surgery. Am Rev Respir Dis (1961) 84, 197207. 


\section{Submaximal exercise testing and respiratory muscle strength in the evaluation for tolerance of lung resection Kousuke OHMORI \\ Second Department of Surgery, Okayama University Medical School, Okayama 700, Japan \\ (Director : Prof. S. Teramoto)}

Exercise test with a treadmill at 2 constant work loads ( 2 and 4 METs) and measurement of MIP were carried out in 73 patients before lung resection. 69 patients underwent surgery and postoperative cardio-pulmonary complications developed in 16. During the exercise, expiratory gas analysis was performed. $\dot{\mathrm{V}} \mathrm{O}_{2} / \dot{\mathrm{V}} \mathrm{E}$ at $4 \mathrm{METs}$ seemed to be useful for the evaluation of the exercise performance and was significantly lower in the cases with complications than in those without $(\mathrm{P}<\mathbf{0 . 0 5})$. MIP was also significantly lower in the cases with complications $(\mathrm{P}<0.01)$. The product of $\mathrm{FEV}_{1.0}\left(\mathrm{ml} / \mathrm{m}^{2}\right)$ by $\dot{\mathrm{V}} \mathrm{O}_{2} / \mathrm{VE}(\%)$ at4METs was defined as "Oxygen uptake index " (OUI). Exercise capacity and development of complications were correlated with OUI more closely than $\mathrm{FEV}_{1.0}$ or $\dot{\mathrm{V}} \mathrm{O}_{2} / \dot{\mathrm{V}} \mathrm{E}$ at $4 \mathrm{MET}$ alone. Postoperative complications developed in $\mathbf{1 5}$ out of 29 cases with a predicted OUI of $\leqq 3300$ and MIP of $\leqq 110 \mathrm{cmH}_{2} \mathrm{O}$, and not in 39 of 40 cases with a predicted OUI of $>3300$ and/or MIP of $>110 \mathrm{cmH}_{2} \mathrm{O}$. Thus, $\mathrm{FEV}_{1.0}, \dot{\mathrm{VO}}_{2} / \dot{\mathrm{VE}}$ at $4 \mathrm{METs}$, and MIP reflect the potentiality of volume, quality, and power of respiratory system, respectively. Therefore, these 3 parameters are considered to be essential and actually useful in the evaluation for tolerance of lung resection. 